\title{
Geoheritage in the Minett UNESCO Biosphere (Southern Luxembourg): Inventory, Evaluation, and Conservation Aspects of Representative Geosites
}

\author{
Robert Weis ${ }^{1,2}$ (D) \\ Received: 18 August 2021 / Accepted: 21 January 2022 / Published online: 1 February 2022 \\ (c) The Author(s) 2022
}

\begin{abstract}
The southwestern part of Luxembourg, known as Minett in the local language use, exposes an exceptionally high diversity of marine near-shore sediment rocks from the Early to Middle Jurassic, owing to its proximal position at the north-eastern margins of the Paris Basin. The iconic Minette ironstone formation is known as the worldwide largest oolitic ironstone deposit from the last 500 my and the abandoned open cast mines are nowadays protected sites with a high biodiversity, intrinsically linked to geodiversity. The schistes bitumineux unit, a lateral equivalent of the well-known Posidonienschiefer of the Holzmaden region (South Germany), is frequently studied for its exceptionally preserved fossils of marine vertebrates, cephalopods, and insect remains, deserving its status as a Fossil-Lagerstätte of international relevance. Of regional importance are the Rumelange limestones, with coral patch-reef paleo-environments. The geomorphological main feature of the region is the Cuesta of the Middle Jurassic ('Dogger-Schichtstufe'), with several outliers ('Zeugenberge') that represent widely visible landmarks in the landscape. In this paper, 16 geosites, representative of the geological, palaeontological, geomorphological, and hydrogeological heritage in the Minett UNESCO biosphere, are presented and evaluated according to scientific, educational, and geotouristic criteria.
\end{abstract}

Keywords Southern Luxembourg · Minette · Geoheritage · Geomorphology · UNESCO Man and the Biosphere programme

\section{Introduction}

In the Grand Duchy of Luxembourg, the concept of geoheritage and its conservation has not been in the focus of national nature conservation agencies until recently (Weis and Di Cencio 2018; Weis 2020). Inventories of geosites and evaluation of geoheritage are currently in an embryonic stage and first results were included in unpublished reports only. Two regions stand up to advocate for their geological heritage: the rural region of the Nature and Geoparc Mëllerdall in the east, where the unique landscape of the Luxembourg Sandstone attracts tourists since the late

Robert Weis

rweis@mnhn.lu

1 Palaeontological Department, Luxembourg National Museum of Natural History, 25 rue Münster,

L-2160 Luxembourg, Luxembourg

2 Minett UNESCO Biosphere Syndicat PRO-SUD, 6 Ellergronn L-4114 Esch-sur-Alzette, Luxembourg, Luxembourg nineteenth century ('Luxembourg's Little Switzerland'), and the Minett UNESCO Biosphere region in the south, where the mining of local iron ore between ca. 1850 and 1981 was at the base of the success of the steel industry in Luxembourg, leaving behind an impressive industrial heritage (Goedert 2020; Kohl 2020). In both areas, the cultural and natural heritage is intrinsically linked with the area's geodiversity. The rocks influence the close relationship between topography, groundwater, building stones, settlement activities, land use, and the highly diversified flora and fauna, often with an outstanding value for biodiversity and natural heritage conservation (Herr \& Colling 2020). In the following, we identify 16 geosites in the Minett UNESCO biosphere region, which are considered representative but not exhaustive, for the region's geodiversity. The geosites are evaluated and classified following scientific, educational, and geotouristic criteria. 


\section{Geological Background}

The area of the Minett UNESCO Biosphere (MUB) is entirely located in the morphostructural unit of the Luxembourgish 'Guttland', at the north-eastern margin of the Paris Basin (N.B.: 'Minett', in Luxembourgish language stands here for the geographic area of south-eastern Luxembourg; in contrast, 'Minette', in French, stands for the Minette iron ore rocks). The Palaeozoic basement (Devonian) that crops out in the northern part of the Grand Duchy, in the region of the Luxembourgish Ardennes named also 'Eislek', is covered here by at least $700 \mathrm{~m}$ of Mesozoic sediments. In the south of Luxembourg, in the Minett region, rocks of early and middle Jurassic age (190-168 my) crop out. The main geological units are as follows:

- Grès Médioliasique (acronym on geological maps: $\operatorname{lm} 3$ ); this unit represents a peculiar facies inserted in the middle Liassic marlstones, chiefly represented in the municipality of Bascharage (Waterlot et al. 1973). It is composed by calcareous sandstone, partially ferruginous, with a thickness of $35-52 \mathrm{~m}$. The age of the unit is late Pliensbachian (ca. 185 my), and it locally contains numerous invertebrate fossils, including ammonites and echinoderms (Fig. 1).
- Schistes Bitumineux (acronym on geological maps: lo1-2); the unit is composed by marlstones and black shales with a considerably high content in organic matter (under the form of kerogen) that were locally studied for their energetic properties during the nineteenth century (Maquil 2010). The unit is dated to the early Toarcian (ca. $182 \mathrm{my}$ ) and encompasses a maximum thickness of $60 \mathrm{~m}$. The sediments contain geochemical signatures witnessing major environmental changes in the epicontinental seas of the Tethys Ocean (e.g. the Toarcian Oceanic Anoxic Event) (Hermoso et al. 2014; Song et al. 2014). Numerous well-preserved fossils are present in the marls and the occasionally occurring carbonate nodules. The nodules in particular contain a diversified vertebrate fauna such as marine reptiles (Godefroit 1994; Vincent et al. 2019; Johnson et al. 2019) and bony fish (Delsate 1997a, 1999a,b,c; Taverne \& Steurbaut 2017), but also numerous invertebrates, namely cephalopods and terrestrial insects (Henrotay et al. 1997; Nel et al. 2004; Nel \& Weis 2017; Bechly 2018), which are particularly well preserved and qualify the deposit as a Konservat-Lagerstätte. There are no permanent outcrops of the Schistes bitumineux, but they are observable during frequent construction works in and around the municipalities of Bascharage, Sanem, Esch-sur-Alzette, Mondercange, Bettembourg, and Dudelange.
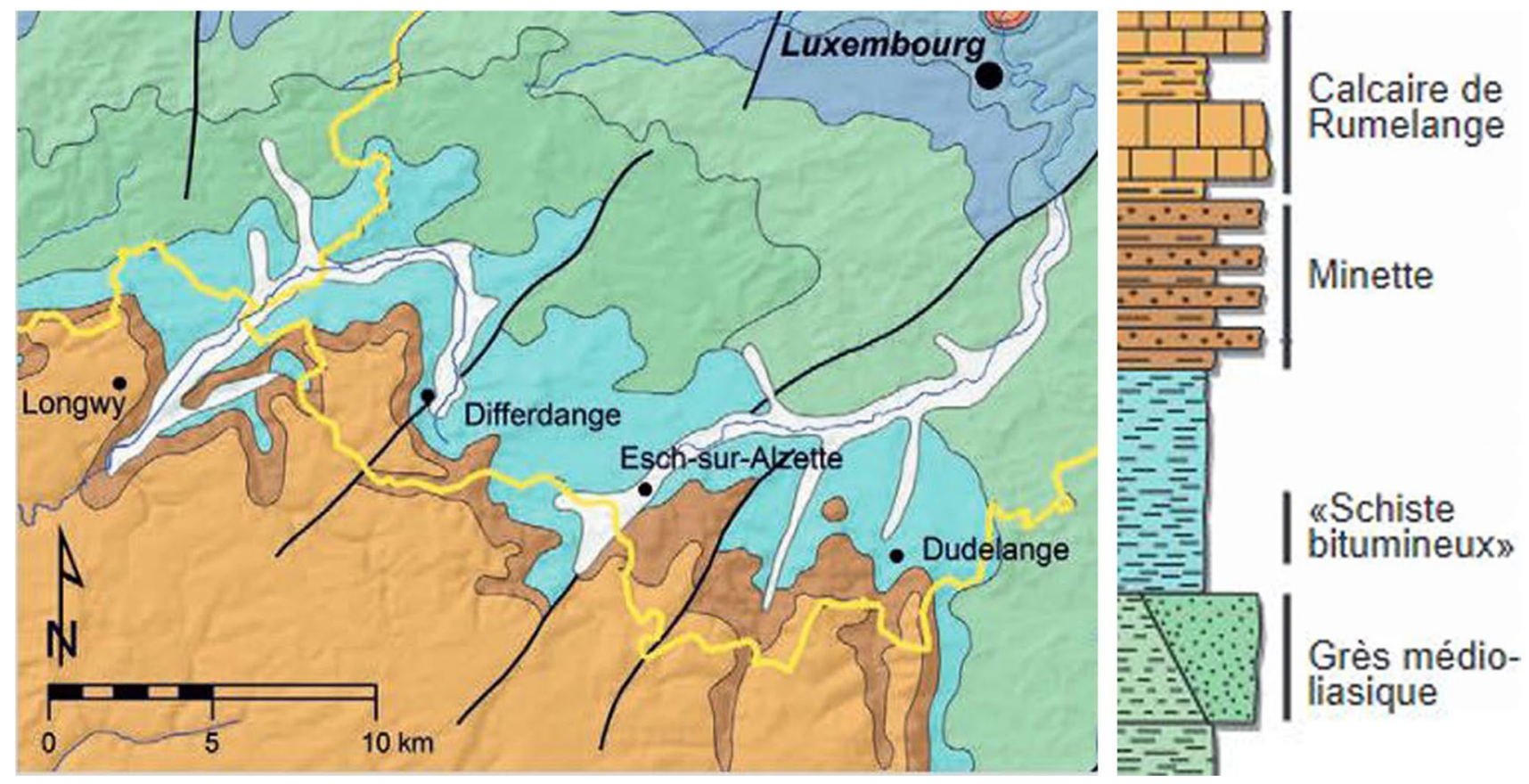

Fig. 1 Simplified geological map of south-western Luxembourg (country border marked with a yellow line). Copyright: Service géologique du Luxembourg, Administration des pont-et-chaussées (www.geologie.lu) 


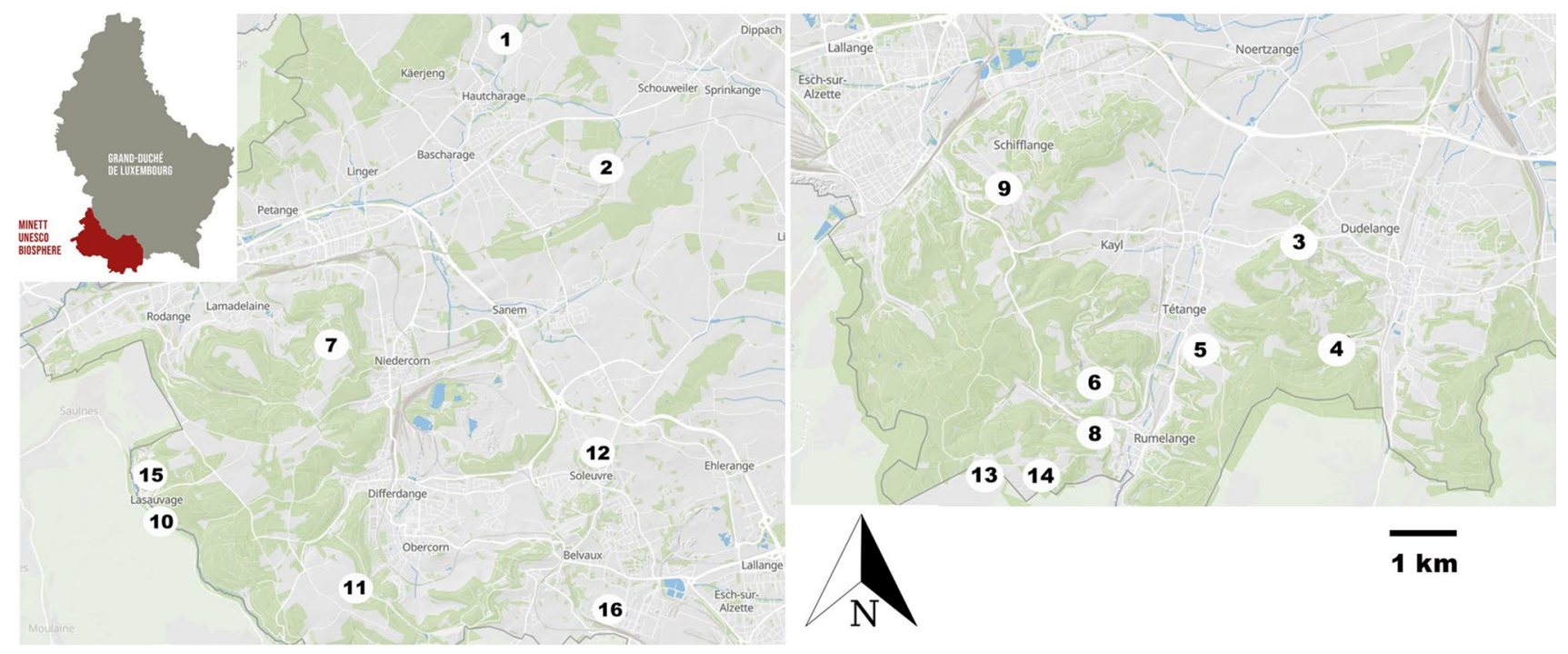

Fig. 2 (a) Position of the Minett UNESCO Biosphere (red colour) in the southern Luxembourg former mining basin; (b) detail of the Differdange-Esch sub-basin, with positions of the geosites as described

- Minette ironstone (acronym on geological maps: lo6, lo7, dou) (Fig. 2); this unit is dated to the Early to Middle Jurassic boundary (ca. 175-170 my) and shows a thickness between 35 and $68 \mathrm{~m}$. It crops out in southern Luxembourg, but extends below the surface into the French Lorraine region and is one of the largest iron ore deposits worldwide. From a geochemical point of view, the rocks are characterised by iron and similar metals as $\mathrm{V}, \mathrm{Ni}, \mathrm{Co}, \mathrm{Mn}$, and $\mathrm{P}$. The high phosphorus content is the reason why the iron ore was not exploited on a large scale until the end of the nineteenth century. The unit shows important lateral facies' variations, especially between the sub-basins of Differdange and Esch-sur-Alzette which are separated by two north-east to south-west striking faults. The Minette iron ore is concentrated as ferruginous oolithes: the iron-rich layers are separated by sterile intermediate layers ('Buch' in the local miner's terminology) and coquina beds ('Bengelëck'). The sequence of intermediate layers, iron ore, and coquina beds follows a sedimentary cycle that represents an evolution from a low-energy towards a high-energy depositional environment. A total number of up to 12 of these cycles can be recognised in the Esch-sur-Alzette sub-basin, against 8 in the Differdange sub-basin (Teyssen 1984; Siehl \& Thein 1989). At the top of the unit, several conglomerates occur, e.g. the so-called Conglomérat à Sonninia, a Konzentrat-Lagerstätte of early Bajocian age containing rich gastropod and ammonite faunas (Sadki et al. 2015; Gatto et al. 2015; Monari \& Gatto 2013a, b; Monari et al. 2018). in the text; (c) detail of the Esch-Dudelange sub-basin, with positions of the geosites as described in the text. Map from Geoportail.lu, Administration du cadastre et de la topographie, Luxembourg

The extraction of the Minette ore has been documented since the Gallo-Roman time period and played a major economic role since the middle of the nineteenth century until 1981, when the last mine was closed down on Luxembourgish territory. Large historical fossil collections are detained by the National Museum of Natural History, in Luxembourg (Weis 2020; Di Cencio \& Weis 2020). Former open cast mining sites allow studying the Minette rocks in the municipalities of Pétange, Differdange, Sanem, Esch-sur-Alzette, Schifflange, Rumelange, Kayl, and Dudelange.

- Calcaires de Rumelange; this unit (acronym on geological maps: dom) is widespread in the municipalities of Differdange and Rumelange. With an early Bajocian age (ca. $169 \mathrm{my}$ ) and an approximate thickness of 60-70 m, the unit is composed by alternating marlstone and limestone containing coral patch reefs (Hary 1970). These rocks are the youngest sedimentary deposits in the Grand Duchy. The limestone has been used since the Gallo-Roman period as construction stone, and the marls and reef limestone are nowadays still used in the production. Noteworthy, palaeontological features are the diversity of fossils from the reef environments (Fayard et al. 2005) and the first dinosaur remains from southern Luxembourg (Delsate et al. 2018). The limestone quarries offer a high educational potential, introducing students to fossils and various Jurassic marine palaeoenvironments. 


\section{Methods}

In this study, only the non-moveable Geoheritage has been taken into account (geosites, geological or geomorphological sites; Crofts et al. 2020). The selection of the 16 geosites has been done according to the following criteria, through a combination of both literature review and collaborations with different actors working on the field, namely private collectors and volunteer collaborators of the Natural History Museum Luxembourg:

- Sites mentioned in an unpublished report on geosites in the Grand-duchy of Luxembourg. This concerns three sites in southern Luxembourg that are considered herein: the Hutbierg-Leffrächen site, the Waisskaul site, and the Griechten site.

- Sites mentioned in regional geological guide and excursion books (Waterlot et al. 1973; Berners et al. 1984). This concerns 3-4 sites.

- Sites that were prospected and/or excavated by members and volunteers of the National Museum of Natural History Luxembourg, between 1984 and 2019. This concerns $4-5$ sites.

- Sites that are classified as national monument (2 sites: Pierre de Cron, Zolverknapp) or that are part of a Museum site (Mine Walert).

The selected geosites have been chosen according to their representativeness. The list should therefore be considered as preliminary, and as a first step to a more complete inventory of geosites in southern Luxembourg and the Grand Duchy as a whole. The evaluation of the geosites following scientific, educational, and geotouristic criteria was conducted using the standards established by Brilha (2016).

\section{Inventory of Geoheritage Sites in the MUB region}

The following 16 sites have been identified and assessed. The sites are listed hereafter according to their geological age. Four geological formations are concerned, of Early to Middle Jurassic age (Pliensbachian to Bajocian stages).

\section{Grès médioliasique Unit (Pliensbachian)}

Geosite 1: 'Griechten' River Section (Hautcharage).

The local denomination 'Griechten' designates a series of micro-canyons cut in the 'Grès-médioliasique' member, northwards the locality of Hautcharage (Fig. 3a). These are among the rare and most representative outcrops in the middle Lias of the area the siltstones yield frequent invertebrate fossils; a remarkable palaeontological feature is the findings of connected brittle stars, particularly rare in Luxembourg, and currently under description as a new taxon (Thuy, in progress). The 'Griechten' are protected as national nature reserve since 2017 and access is strictly limited.

\section{Schistes bitumineux Unit (Lower Toarcian)}

Geosite 2: 'ZAE Edward Steichen ' Fossil Site (Bascharage).

The Bascharage area is widely known as a KonservatLagerstätte for its well-preserved fossil faunas from the lower Toarcian (Godefroit 1994; Henrotay et al. 1998; Delsate \& Maubeuge 2000). The industrial activity
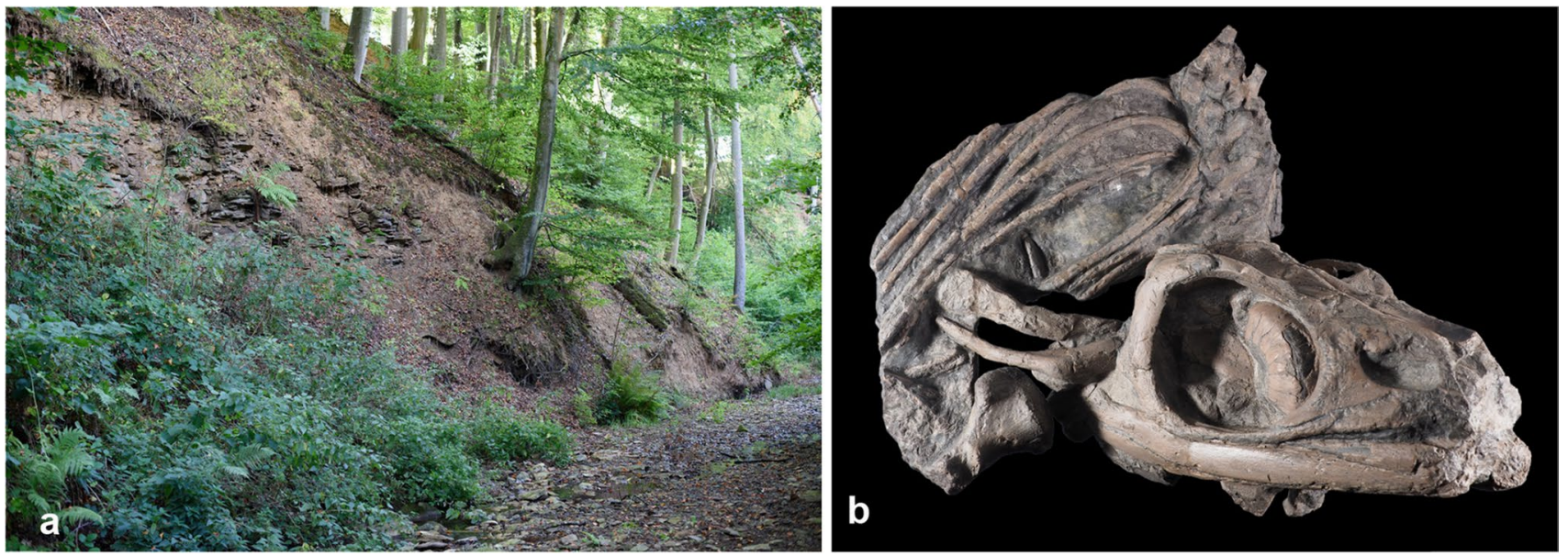

Fig. 3 Minett UNESCO Biosphere geosites, part 1: (a) geosite 1, 'Griechten' river section with outcropping 'Grès médioliasique' nearby Hautcharage; photo R. Weis in March 2020; (b) geosite 2, fos- sil skull and thorax of a marine reptile (Ichthyosaur), Stenopterygius sp., ZAE Edward Steichen, Bascharage.; coll. Luxembourg Museum of Natural History $n^{\circ}$ TV603, photo Denis Hillebrandt/MNHNL 
zone Edward Steichen (formerly Z. I. Bommelscheier and Z. I. Op Zaemer) yielded several temporarily accessible excavation sites especially during the early' 90 of the last century. Joint venture excavations between the Luxembourg National Museum of Natural History and the 'Institut Royal des Sciences de Belgique' (Bruxelles) resulted in many fossils (Fig. 3b) that are now preserved in Brussels (vertebrates mainly) and Luxembourg (311 specimens in the collections of the Luxembourg National Museum of Natural History). Private collectors also gathered important fossil collections that nowadays are partially in public repositories, such as an important insect collection (former coll. M. Henrotay), preserved now at the Muséum d'histore naturelle in Paris. The site is type locality of several insect species (Nel et al. 2004; Szwedo 2011; Bechly 2018). Currently (2020), outcrops are not accessible, though new construction works are planned until 2030.

\section{Minette Ironstone Unit and Conglomérat à Sonninia Bed (Upper Toarcian to Lowermost Bajocian)}

Geosite 3: 'Galgebierg-Scherr' Site (Dudelange).

The site presents a natural ravine (Fig. 4a) exposing the Grès à Dumortieria (Lucius 1945), a local marly-sandy facies of the Minette formation that is devoid of iron ooids (Waterlot et al. 1973). The site has yielded also ammonites and belemnites of upper Toarcian age, and is currently still accessible.

Geosite 4: 'Quartier italien' Fossil Site (Dudelange).

A former open cast mining site nearby the neighbourhood is called 'Italie' in the city of Dudelange (Fig. 4b). Here, the Minette iron ore, and specifically the top of the 'Couche grise' cycle, has yielded numerous ammonites of the genus Pleydellia, described as new species by Maubeuge (1947, 1950) and re-described by Di Cencio and Weis (2020). The site is for instance the type locality of Pleydellia buckmani Maubeuge, 1947, an index ammonite for the Buckmani horizon, Pseudolotharingicum Subzone, Aalenis Zone, in the uppermost Toarcian (Di Cencio \& Weis 2020). Currently, the site is overgrown and fenced, as it is part of a former industrial site.

Geosite 5: 'Hesselsbierg' Former Open Cast Iron Mine (Tétange).

The Hesselsbierg former open cast mining site exposes an impressive cliff showing the particularly well-developed Couche jaune cycle of the Minette formation (Fig. 4c). It is part of a larger system of open cast pits that extended from Kayl in the north to Rumelange in the south, and nowadays part of the nature protection area 'Haard-Hesselsbierg-Staebierg'.
Geosite 6: 'Hutbierg' Former Open Cast Iron Mine (Rumelange).

The former Hutbierg iron mine, on the slopes of the Holleschbierg hill nearby Rumelange and now part of the nature reserve 'Leffrächen', is an internationally known palaeontological and geomorphological site (Fig. 4d), exposing also very well the sedimentary sequence from the Minette Formation (uppermost Toarcian) towards the Bajocian marls and limestones (Achilles \& Schulz 1980; Järling 1992; Guérin-Franiatte \& Weis 2010). The collections of the Luxembourg National Museum of Natural History preserve circa 560 specimens from the Hutbierg site, comprising the holotypes of a new belemnite species (Weis \& Mariotti 2008) and a new brittlestar (Numberger-Thuy \& Thuy 2015). Most fossils are stratigraphically important ammonites from the Aalenian Murchisonae and Concavum zones (Guérin-Franiatte \& Weis 2010; Sadki et al. 2020).

Geosite 7: 'Giele Botter' Former Open Cast Iron Mine (Differdange).

The former open cast mines in the Giele Botter-Prënzebierg area, are nowadays a protected nature reserve. The area is accessible for visitors, which can follow a 3-km long geological trail (Circuit géologique Giele Botter). The outcrop of the Toarcian-Aalenian Minette formation (Thein 1975) and the overlying rocks from the Marnes micacées and Couches à Sonninia members (Bajocian: Köwius 1977; Sadki et al. 2015) are still well exposed and can easily be studied in situ (Berners et al. 1984). The Couches à Sonninia also contain a conglomeratic bed (Fig. 4e), the 'Conglomérat à Sonninia' (Lucius 1945; Sadki et al. 2015), and a Konservat-Lagerstätte that yielded exceptionally well-preserved marine invertebrate fossils, namely gastropods (Gatto et al. 2015; Monari \& Gatto 2013a, b; Monari et al. 2018), echinids (Thuy 2010a), ammonites, and belemnites (Maubeuge 1994b; Sadki et al. 2015).

Geosite 8: Underground Iron Mine Walert (Rumelange).

This underground iron mine is well preserved and can be visited as a part of the National Mining Museum (Musée national des mines de fer de Rumelange; Fig. 4f). The different iron ore cycles that were exploited here until 1964 can be studied in situ.

Geosite 9: 'Lalléngerbierg' former Open Cast Mine (Esch-sur-Alzette).

The Lalléngerbierg open cast mining area is protected nowadays as a national nature reserve. The sedimentological sequence of the Minette ironstones is still well visible nowadays (Fig. 4g) (Waterlot et al. 1973; Achilles \& Schulz 1980), and it is a reference outcrop for the Minette sequence in the Esch-sur-Alzette sub-basin (Berners et al. 1984).

Geosite 10: Vallée de la Crosnière Old Quarry Site (Lasauvage).

A small open cast mine cut onto the wooded slopes eastwards of the former miner's village of Lasauvage is part of 

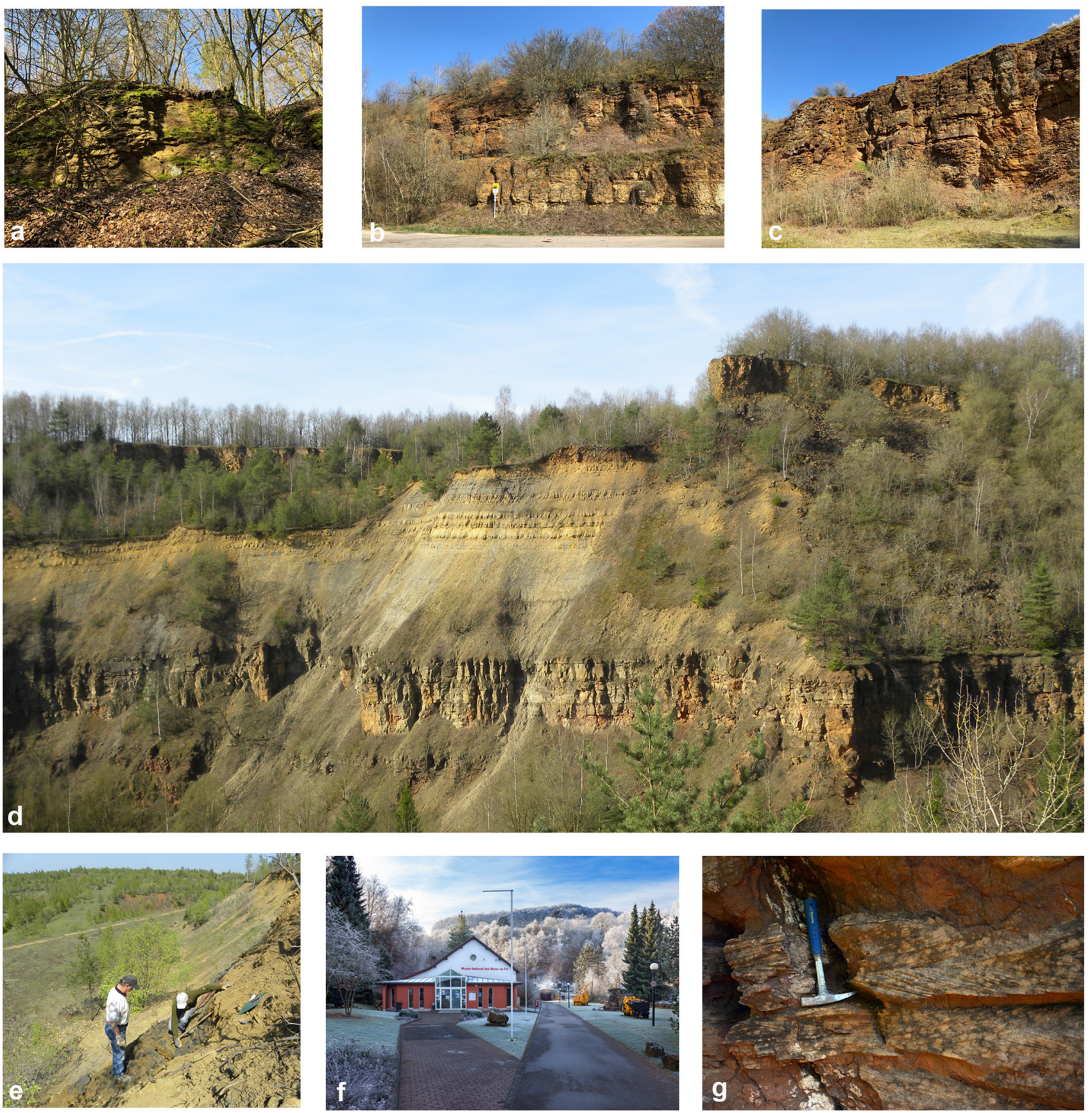

Fig. 4 Minett UNESCO Biosphere geosites, part 2: (a) geosite 3, ravine Galgenbierg-Scheer nearby Dudelange, exposing the 'Grès à Dumortieria'; photo by R. Weis/MNHNL, March 2020; (b) geosite 4, Couche grise and Couche jaune cycles of the Minette ironstone formation at locality 'Italie' nearby Dudelange; photo by R. Weis/ MNHNL, March 2020; (c) geosite 5, ironstone cliff at the Hesselsbierg hilltop, nearby Tétange; photo by R. Weis/MNHNL, March 2020; (d) geosite 6, overview of a rock sequence comprising the upper part of the Minette formation and the overlying marls and limestones of the Bajocian, former open cast mine Hutbierg nearby
Rumelange; photo by R. Weis/MNHNL, April 2017; (e) geosite 7, palaeontological excavation in the 'Conglomérat à Sonnina' Konzentrat-Lagerstätte (early Bajocian) at Giele Botter, nearby Differdange in 2013; photo by R. Weis/MNHNL; (f) geosite 8, entrance of the National Mining Museum and the underground mine 'Walert', in Rumelange; photo by Musée national des Mines de fer Rumelange; (g), Geosite 9, Cross-stratifications in situ, a detail of the sandwave complex building up the Minette sedimentological cycles at former open cast mine 'Lalléngerbierg' nearby Esch-sur-Alzette; photo by R. Weis/MNHNL, 2017 

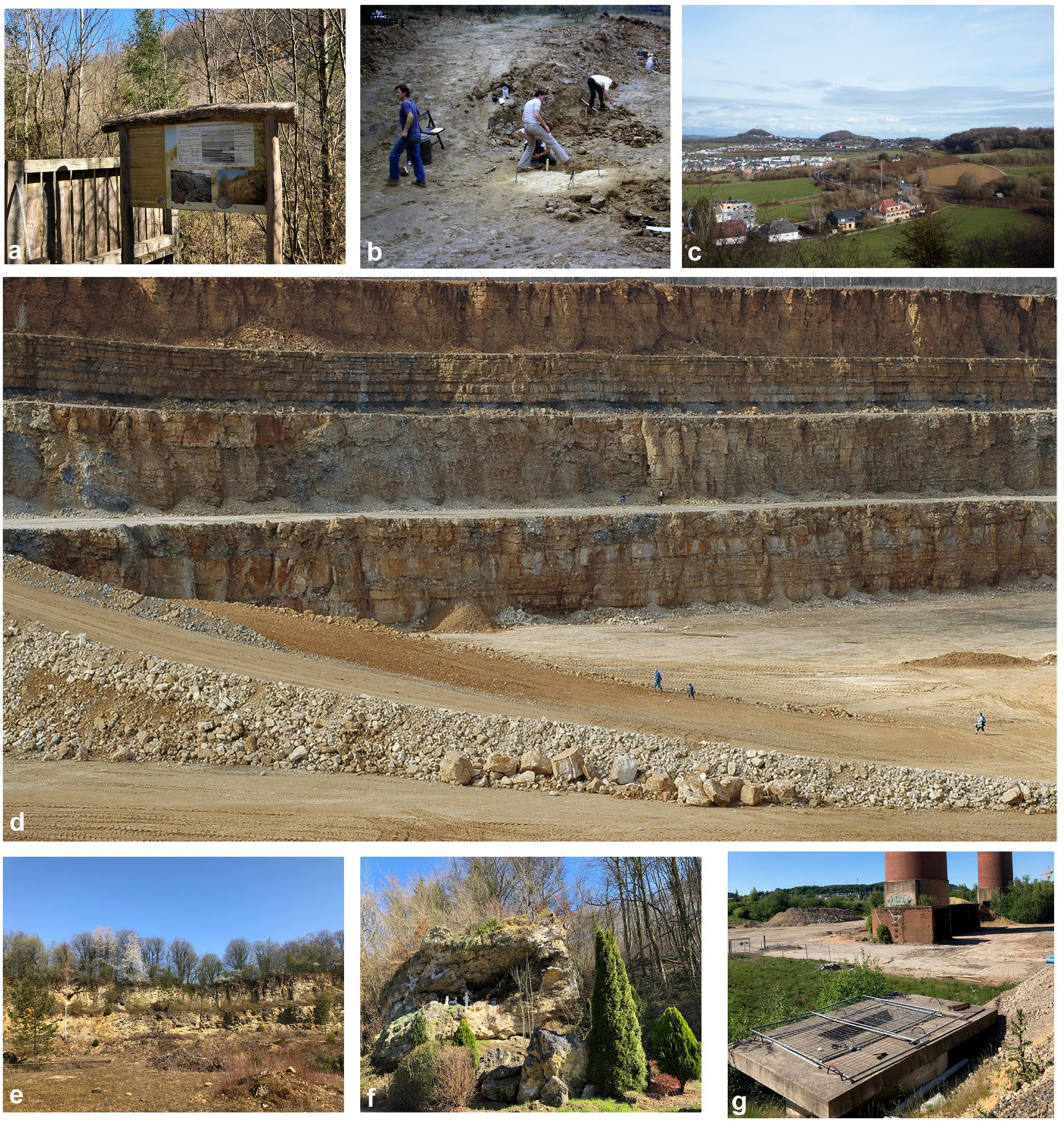

Fig. 5 Minett UNESCO Biosphere geosites, part 3: (a) geosite 10, explanatory panel about local geology at the nature trail in the 'Crosnières' valley nearby Lasauvage; photo by R. Weis/MNHNL, March 2020; (b) geosite 11, excavations by collaborators of the Luxembourg National Museum of Natural History at the 'Rollesbierg-Kiemerchen' fossil site, nearby Differdange, in 1984; photo by A. Faber/MNHNL; (c) geosite 12, the Zolverknapp, Loetschet, Pakebierg and Galgebierg hilltops seen from Obercorn; photo by K. Totaro, February 2021; (d) geosite 13, view of the active quarry 'op der hënneschter
Heed' nearby Rumelange, showing the 'Calcaire de Rumelange' unit; photo by R. Felten/MNHNL; (e) geosite 14, view of the abandoned and partially overgrown quarry site 'Waisskaul' nearby Rumelange, showing the Bajocian coral reef facies; photo by R. Weis/MNHNL, March 2020; (f) geosite 15, travertine rock 'Pierre de Cron', nowadays a place of whorship; photo by R. Weis/MNHNL, March 2020; (g) geosite 16, former site of the Bel-Val well near the locality of Belvaux, currently an abandoned industrial wasteland; photo by R. Weis/ MNHNL, March 2020 
the pedagogical nature trail through the valley of the Crosnière creek (Fig. 5a). The outcrop shows the upper part of the Minette formation and the passage towards the overlying Bajocian marls and limestones in the Differdange basin; unfortunately, it is nowadays partially overgrown by vegetation and geological observations are difficult under the given circumstances.

Geosite 11: 'Rollesbierg-Kiemerchen' Fossil Site (Obercorn).

This site, now overgrown by vegetation, is situated in the nature reserve Kiemerchen, at the slope of the Rollesbierg hill. In the 1980, it yielded a well-preserved invertebrate fossil fauna from the 'Conglomérat à Sonninia' (Fig. 5b) (Lucius 1945; Sadki et al. 2015), a Konzentrat-Lagerstäte of early Bajocian age, that crops also out in the neighbouring 'Giele Botter' geosite. Fossils include remarkably diverse gastropods (Gatto et al. 2015; Monari \& Gatto 2013a, b; Monari et al. 2018), echinids (Thuy 2010a), ammonites, and belemnites (Maubeuge 1994b; Sadki et al. 2015). The collections of the Luxembourg National Museum of Natural History preserve a total number of 421 specimens from the Rollesbierg site, giving a rather complete overview about the early Bajocian marine palaeofauna.

Geosite 12: 'Zolverknapp-Loetschet-Pakebierg' Geomorphological Site (Sanem).

The mounds (French: 'Butte témoin') of Zolverknapp, Loetschet, and Pakebierg, nearby the locality of Soleuvre, form a widely visible landmark (Storoni 2010). The hill tops, culminating at 422,396 , and $380 \mathrm{~m}$, respectively, are composed of erosion-resistant rocks of the lower part of the Minette formation (Fig. 5c). The Zolverknapp hill, classified and protected as a national monument, features several viewpoints, which allow outlooks towards the plain of the middle Liassic. This triple mound range also forms the watershed between the Meuse river system westwards and the Rhine river system eastwards (Storoni 2010).

\section{Calcaire de Rumelange Unit (Lower Bajocian)}

Geosite 13: 'Op der hënneschter Heed', Active Limestone Quarry (Rumelange-Ottange).

This impressive cross-border quarry site (Fayard et al. 2005; Weis 2006), active since the'70 of the last century, is included herein although the major part is situated on French territory. It represents a major geological site in the whole NE Paris Basin, attracting geologist and fossil hunters alike from all over Europe (Fayard et al. 2005). Four lithostratigraphic members are outcropping at the different levels of the quarry (Fig. 5d), notably the 'Calcaire d'Audun-le-Tiche' with coral patch reefs (Lucius 1945; Hary 1970; Geister 1984, 1986; Lathuilière 2000a,b) and the 'Marnes sableuses d'Audun-le-Tiche' with namely large cephalopods (Weis 2006), fish teeth (Delsate \& Felten 2015; Popov et al. 2019), echinids (Thuy 2003, 2010b), and marine reptile remains (Fischer et al. 2021), as well as a single dinosaur osteoderm (Delsate et al. 2018). The site has high educational potential and access is possible to professionals, under certain conditions and with a special permit.

Geosite 14: 'Waisskaul', Abandoned Limestone Quarry (Rumelange).

This abandoned quarry site shows the impressive coral reef facies (Fig. 5e) of the Calcaire de Rumelange (Lucius 1945; Hary 1970; Waterlot et al. 1973; Berners et al. 1984). The quarry is situated in a Natura2000 protected zone, and has recently been cleaned from vegetation (2013); geological observations are currently possible, although access is subject to a special permit. The numerous fossils from the Waisskaul have been occasionally described (corals and ammonites: Hary 1970; echinids: Thuy 2003).

\section{Post-Mesozoic Sites}

Geosite 15: 'Pierre de Cron', Travertine Rock (Lasauvage). The travertine rock mass, called 'Pierre de Cron' (FR) or 'Dauschsteen' (L), is a well-known feature in the former miner's village of Lasauvage, and part of local folkloristic tales (Fig. 5f). It is protected by law as a national monument since 2015. It is the only travertine rock of these dimensions in the south of Luxembourg.

Geosite 16: 'Source Bel-Val', Artesian Well (Belvaux).

In the area of the village of Belvaux, the Schistes Bitumineux unit is cut by a minor fault line (Maquil 2010); along this fault-line, an artesian well has been discovered in the late nineteenth century (d'Huart 1892). The mineral water of the well was extracted commercially and shipped worldwide until 1935 (Gengler 1980). Later, the site of the well was covered by industrial installations (Belval steel works), and currently, it is hidden under industrial wasteland (Fig. 5g). More recently, a project has been presented by the local municipality with the aim of making the site of the 'Source Bel-Val' accessible again as a recreational area in 2022 (Coubray 2020).

\section{Evaluation of the Studied Geosites: Results}

The 16 reported geosites have been analysed according to scientific, educational, and touristic critera, following the methodology developed by Brilha (2016): the results are exposed in Tab. 1. Considering the average values, most remarkable geosites include the Giele Botter site (geosite 12), the quarry 'op der henneschter Heed' (geosite 18), and the Hutbierg site (geosite 11). These three sites are also the ones featuring the highest scientific value. 
Table 1 Assessment of geosites in the Minett UNESCO

Biosphere, after Brilha (2016)

\begin{tabular}{lllll}
\hline Geosite & Scientific V & Educational V & Touristic V & Average V \\
\hline Giele Botter (7) & 320 & 220 & 250 & $\mathbf{2 6 3}$ \\
Heed quarry (13) & 350 & 230 & 185 & $\mathbf{2 5 5}$ \\
Hutbierg (6) & 330 & 220 & 205 & $\mathbf{2 5 2}$ \\
Hesselsbierg (5) & 170 & 255 & 250 & $\mathbf{2 2 5}$ \\
Mine Walert (8) & 115 & 255 & 285 & $\mathbf{2 1 8}$ \\
Waisskaul (14) & 245 & 195 & 205 & $\mathbf{2 1 5}$ \\
Crosnière (10) & 95 & 255 & 275 & $\mathbf{2 0 8}$ \\
Petite Italie (4) & 190 & 215 & 215 & $\mathbf{2 0 7}$ \\
Source Belval (16) & 215 & 200 & 185 & $\mathbf{2 0 0}$ \\
Lalléngerbierg (9) & 150 & 215 & 210 & $\mathbf{1 9 2}$ \\
Gaalgebierg (3) & 95 & 220 & 240 & $\mathbf{1 8 5}$ \\
Zolverknapp (12) & 90 & 225 & 215 & $\mathbf{1 7 7}$ \\
Pierre de Cron (15) & 205 & 150 & 155 & $\mathbf{1 7 0}$ \\
Kiemerchen (11) & 120 & 190 & 195 & $\mathbf{1 6 8}$ \\
Griechten (1) & 190 & 150 & 155 & $\mathbf{1 6 5}$ \\
Edward Steichen (2) & 145 & 135 & 125 & $\mathbf{1 3 5}$ \\
\hline
\end{tabular}

Meanwhile, the sites with most educational potential are the Walert Mine (geosite 13), which is already part of a Museum site, and thus easily accessible to the public, and the Hesselsbierg (geosite 10), one of the most impressive red-coloured cliffs in the whole area. The sites with the highest touristic potential are, once again, the Walert mine museum site (geosite 13), and the Crosnières site nearby Lasauvage (geosite 15), which is part of a nature trail in an area with high touristic potential, a potential that will be further developed in the coming years. The lowest values for educational and touristic values are attributed to those sites which are currently inaccessible, either for current lack of outcrop (geosite 2) or for strict nature preservation policies (geosite 1).

\section{Discussion}

The present study is intended as a first step towards an inventory and assessment of geosites in southern Luxembourg's Minett UNESCO Biosphere region. As a further step after site inventory and selection, propose two stages: (1) the analysis of conservation needs and (2) conservation planning and delivery. Applied to Luxembourg, this would

Table 2 Protection status and degradation risk (based on Brilha 2016) of geosites in the Minett UNESCO Biosphere

\begin{tabular}{lll}
\hline Geosite & Protection status & Degradation risk \\
\hline Giele Botter (7) & Nature Reserve 'Prënzebierg ' (since 1991) & Low \\
Heed quarry (13) & Active quarry & High \\
Hutbierg (6) & Nature Reserve 'Léiffrächen' (since 2019) & Low \\
Hesselsbierg (5) & Nature Reserve 'Haard-Hesselsbierg-Staebierg '(since 1994) & Low \\
Mine Walert (8) & Museum site & Low \\
Waisskaul (14) & Natura2000 zone & Moderate \\
Crosnière (10) & Natura2000 zone & Moderate \\
Petite Italie (4) & Nature Reserve 'Haard-Hesselsbierg-Staebierg '(since 1994) & High \\
Source Belval (16) & n/a & High \\
Lalléngerbierg (9) & Nature Reserve 'Brucherbierg-Lalléngerbierg' (since 2016) & Low \\
Gaalgebierg (3) & Nature Reserve 'Haard-Hesselsbierg-Staebierg ' (since 1994) & Low \\
Zolverknapp (12) & Classified as National Monument & Low \\
Pierre de Cron (15) & Classified as National Monument & Moderate \\
Kiemerchen (11) & Nature Reserve 'Kiemerchen/Scheiergronn/Groussebësch' (since 2020) & Low \\
Griechten (1) & Nature Reserve 'Griechten' (since 2017) & Low \\
Edward Steichen (2) & n/a & High
\end{tabular}


imply the establishment of site documentation reports for example in the framework of a hypothetical national Geoheritage inventory. Currently, no geoconservation management mesures are applied in the Minett UNESCO Biosphere. However, a legal protection of geological sites is in several cases implicitly provided as they often coincide with biodiversity hotspots (national nature reserves or European Natura2000 network) (Tab. 2). In rare cases, geological sites were classified as a national monument. However, explicit recognition of the geological heritage of these sites is not yet given. Reinforcing the work capacity of nature conservation agencies and inclusion of geoconservation strategies in the management of the areas greatly contribute to valorize geoheritage as the "natural link' between natural and cultural heritage.

\section{Conclusion}

The geoheritage in the Minett UNESCO Bisophere is intrinsically linked to former mining activities: it comprises geosites and geomorphosites as well as geological collections of international significance. Recognition of the importance of geoheritage and its potential for scientific, educational activities, and the development of "slow tourism' seems especially rewarding in case of the former mining sites, nowadays classified as national nature reserves. An inventory of geosites, with a focus on sites representative of the area's geodiversity, is a first step, attempted in this publication. On a long-term perspective, reinforcing the work capacity of nature conservation agencies and inclusion of geoconservation strategies in the management of protected areas would greatly contribute to valorise the role of geoheritage as the 'natural link' between natural heritage and cultural/industrial heritage; geoheritage appears therefore as a suitable field of research to fulfil the scientific goals and missions of the UNESCO Man and the Biosphere programme.

Acknowledgements The author would like to thank Alain Faber and Ben Thuy (MNHNL) for their continuous support during this project. A special thanks also to Gaëlle Tavernier, general manager of the Minett UNESCO Biosphere, and Jan Herr (Administration de la nature et des forêts) for their interest in geoconservation issues. Romain Meyer and Robert Colbach (Service géologique du Luxembourg-SGL) are thanked for providing information about the Bel-Val well. The following persons or associations have contributed with photographs: Denis Hillebrandt, Paul Braun, Ben Thuy, Alain Faber, Roland Felten (all MNHNL), Kim Totaro (SGL). Two anonymous reviewers greatly contributed to improving the present paper.

Funding Research was supported and funded by the National Museum of Natural History, Luxembourg. Figure 1

\section{Declarations}

Conflict of Interest The author declares no competing interests.

Open Access This article is licensed under a Creative Commons Attribution 4.0 International License, which permits use, sharing, adaptation, distribution and reproduction in any medium or format, as long as you give appropriate credit to the original author(s) and the source, provide a link to the Creative Commons licence, and indicate if changes were made. The images or other third party material in this article are included in the article's Creative Commons licence, unless indicated otherwise in a credit line to the material. If material is not included in the article's Creative Commons licence and your intended use is not permitted by statutory regulation or exceeds the permitted use, you will need to obtain permission directly from the copyright holder. To view a copy of this licence, visit http://creativecommons.org/licenses/by/4.0/.

\section{References}

Achilles H, Schulz HJ (1980) Geologische Untersuchungen in der Minette des Escher Beckens (Luxemburg). Revue technique luxembourgeoise 3, juillet-septembre 1980:93-141

Bechly G (2018) First record and a new species of the fossil dragonfly genus Proinogomphus (Odonata Liassogomphidae) from the Early Jurassic of Bascharage in the Grand. Duchy of Luxembourg Zootaxa 4450:108-114. https://doi.org/10.11646/zootaxa.4450.1.7

Berners HP, Bintz J, Teyssen T (1984) Unterer und mittlerer Jura im Luxemburger Gutland (Exkursion G am 26. Und 27. April 1984). Jber Mitt Oberrhein Geol Ver 66:95-106

Brilha J (2016) Inventory and quantitative assessment of geosites and geodiversity sites: a review. Geoheritage 8:119-134

Coubray C (2020) Le Pavillon Source Bel-Val a son concepteur. PaperJam, published online 27 November 2020. https://paperjam.lu/ article/pavillon-source-bel-val-a-son-. Accessed 4 March 2021

Crofts R, Gordon JE, Brilha J, Gray M, Gunn J, Larwood J, Santucci VL, Tormey D, Worboys GL (2020) Gudielines for geoconservation in protected and conserved areas. Best Practice Area Guidelines Series 31:1-125. IUCN, Gland, Switzerland.

d'Huart E (1892) Étude sur l'eau d'Ernshof source Bel-Val. Imprimerie de la Cour V. Bück, Luxembourg

Delsate D (1999c) L'Ichthyofaune du Toarcien luxembourgeois. Cadre général et Catalogue statistique. Travaux Scientifiques Du Musée National D'histoire Naturelle De Luxembourg 30:1-101

Delsate D, Maubeuge PL (2000) Le Toarcien inférieur des régions de Bascharage et de Bettembourg (Grand-Duché de Luxembourg). A propos d'une soi-disant émersion fugitive, ou d'environnements restreints proches de l'émersion. Arch Inst Grand-Ducal Luxembourg Sect Sc Nat Phys Et Math 43:55-71

Delsate D, Godefroit P, Stomp N, Faber A, Massard J, Maubeuge PL, Boulvain F, Roche M (1999) Remarques sur l'article de Henrotay, Marques, Paicheler, Gall \& Nel (1998): Le Toarcien inférieur des régions de Bascharage et de Bettembourg (Grand-Duché du Luxembourg): évidences paléontologiques et sédimentologiques d'environnements restreints proches de l'émersion. Bull Acad Soc Lorr Sci 38:15-27

Delsate D, Pereda-Suberbiola X, Felten R, Felten G (2018) First thyreophoran dinosaur from the Middle Jurassic (Bajocian) of Luxembourg. Geol Belg 21(1-2):19-26

Delsate D, Felten R (2015) Chondrichthyens et Actinoptérygiens du Bajocien inférieur du Grand-duché de Luxembourg et des régions frontalières. In: Weis R, Thuy B (eds) Le Jurassique au 
Luxembourg (1). Vertébrés, échinodermes et céphalopodes du Bajocien. Ferrantia 71:9-38

Delsate D (1997a) Actinoptérygiens du Toarcien inférieur du GrandDuché de Luxembourg : Présence de Leptolepis normandica Nybelin 1962 (Téléostéen) avec otolithes in situ. In: Maubeuge PL, Delsate D (eds) Notes paléontologiques et biostratigraphiques sur le Grand-duché de Luxembourg et les régions voisines, Travaux scientifiques du Musée d'Histoire Naturelle de Luxembourg 27:105-129

Delsate D (1999a) Haasichthys michelsi, nov. gen., nov. sp., un nouveau Pachycormiforme (Osteichtyes, Actinopterygii) du Toarcien inférieur (Jurassique) luxembourgeois. In: Delsate D, Duffin C, Weis R (eds) Les collections paléontologiques du Musée national d'histoire naturelle de Luxembourg. Fossiles du Trias et du Jurassique, Travaux scientifiques du Musée national d'histoire naturelle de Luxembourg 32:87-140

Delsate D (1999b) Un Pholidophoridae nouveau (Osteichthyes, Actinopterygii) du Toarcien (Jurassique inférieur) luxembourgeois. In: Delsate D, Duffin C, Weis R (eds) Les collections paléontologiques du Musée national d'histoire naturelle de Luxembourg. Fossiles du Trias et du Jurassique, Travaux scientifiques du Musée national d'histoire naturelle de Luxembourg 32:141-205

Di Cencio A, Weis R (2020) Revision of upper Toarcian ammonites (Lytoceratidae, Graphoceratidae and Hammatoceratidae) from the Minette ironstones, southern Luxembourg. In: Di Cencio A, Sadki D, Weis R (eds) Paléontologie au Luxembourg (2). Les ammonites de la Minette. Ferrantia 83:5-103

Fayard JP, Gross N, Lajournade B, Lathuilière B, Vailly G, Weis R (2005) Fossiles et minéraux de la carrière d'Ottange-Rumelange. Géolor/Thionville and AGMP/Dudelange

Fischer V, Weis R, Thuy B (2021) Refining the marine reptile turnover at the Early-Middle Jurassic transition. PeerJ. https://peerj.com/ articles $/ 10647$

Gatto R, Monari S, Szabó J, Conti MA (2015) The Jurassic pleurotomarioidean gastropod Laevitomaria and its palaeobiogeographical history. Acta Palaeontol Pol 60(1):217-233

Geister J (1984) Récifs à coraux du Bajocien du Grand-Duché de Luxembourg et de Malancourt en Lorraine. In: Geister J, Herbs E (eds) Géologie et paléoécologie des récifs. Institut de Géologie de l'Université de Berne 13:1-12

Geister J (1986) Taux de croissance et production de carbonates d'un récif corallien bajocien (Rumelange, Grand-Duché de Luxembourg). Fossil Cnidaria 15:13-14

Gengler G (1980) « Societé Fermière Belval 1888 », « Société anonyme générale des eaux minérales de Bel-Val 1895 », « Mineralbrunnen-AG Bel-Val $1920 »$. Cercle vocal Belval-Metzerlach

Godefroit P (1994) Les reptiles marins du Toarcien belgo-luxembourgeois. Mémoires Pour Servir à L'explication Des Cartes Géologiques Et Minières De La Belgique 39:1-98

Goedert J (2020) Le Minett - un paysage urbanisée postindustriel. Mutations - Mémoires et perspectives du bassin minier 11:57-61. Fondation Bassin Minier, Luxembourg

Gordon JE, Crofts R, Díaz-Martínez E (2017) Geoheritage conservation and environmental policies. Retrospect and prospect. In: Reynard E, Brilha J (eds) Geoheritage. Assessment, protection and management:213-236

Guérin-Franiatte S, Weis R (2010) Le passage Aalénien-Bajocien près de Rumelange : la série biostratigraphique dans le Bassin d'Eschsur-Alzette (Grand-duché de Luxembourg). In: Weis R, GuérinFraniatte $\mathrm{S}$ (eds) Le Jurassique inférieur et moyen au Luxembourg. Nouvelles données paléontologiques et biostratigraphiques, Ferrantia - Travaux scientifiques du Musée national d'histoire naturelle Luxembourg 62:73-96
Hary A (1970) Récifs de coraux du Bajocien Moyen aux environs de Rumelange. Arch Inst Grand-Ducal Luxembourg Sect Sc Nat Phys Et Math 34:431-455

Henrotay M, Nel A, Jarzembowski EA (1997) New protomyrmeleontid damselflies from the Triassic of Australia and the Liassic of Luxembourg, with the description of Tillyardomyrmeleon petermilleri gen. nov. \& spec. nov. (Archizygoptera: Protomyrmeleontidae). Odonatologica 26:395-404

Henrotay M, Marques D, Paicheler JC, Gall JC, Nel A (1998) Le Toarcien inférieur des régions de Bascharage et de Bettembourg (grand-duché du Luxembourg): évidences paléontologiques et sédimentologiques d'environnements restreints proches de l'émersion. Geodiversitas 20(2):263-284

Hermoso M, Delsate D, Baudin F, Le Callonnec L, Minoletti F, Renard M, Faber A (2014) Record of Early Toarcian carbon cycle perturbations in a nearshore environment: the Bascharage section (easternmost Paris Basin). Solid Earth 5:793-804

Herr J, Colling G (2020) Die Biodiversität der ehemaligen Tagebaugebiete der Minette-Region. Mutations - Mémoires et perspectives du bassin minier 11:49-55. Fondation Bassin Minier, Luxembourg

Järling I (1992) Etude géomorphologique des friches industrielles du bassin minier du Luxembourg avec leurs possibilités de réaffectation. Exemple : les exploitations à ciel ouvert. Dissertation, University Louis Pasteur, Strasbourg

Johnson MM, Young MT, Brusatte SL, Thuy B, Weis R (2019) A catalogue of teleosauroids (Crocodylomorpha: Thalattosuchia) from the Toarcian and Bajocian (Jurassic) of southern Luxembourg. Hist Biol 31(9):1179-1194

Kohl J (2020) La culturelle industrielle comme marque d'une région. Mutations - Mémoires et perspectives du bassin minier 11: 85-94. Fondation Bassin Minier, Luxembourg

Köwius B (1977) Sedimentologisch-stratigraphische Untersuchungen im unteren und mittleren Bajocien Luxemburgs. Dissertation, Friedrich-Wilhelms-Universität Bonn

Lathuilière B (2000) Les coraux constructeurs du Bajocien inférieur de France 1ère partie. Geobios 33(1):51-72

Lathuilière B (2000) Les coraux constructeurs du Bajocien inférieur de France 2ième partie. Geobios 33(2):153-181

Lucius M (1945) Die Luxemburger Minetteformation und die jüngeren Eisenerzbildungen unseres Landes. Beiträge zur Geologie von Luxemburg 4:1-347. Service Carte géologique du Luxembourg

Maquil R (2010) Le sous-sol de Belval. Magazine, Le Périodique Du Fonds Belval 3(2010):25-31

Maubeuge PL (1947) Sur quelques ammonites de 1'“Aalénien Ferrugineux" du Luxembourg et sur l'échelle stratigraphique de la formation ferrifère franco-belgo-luxembourgeoise. Arch Inst Grand-Ducal Luxembourg Sect Sc Nat Phys Et Math 17:73-87

Maubeuge PL (1950) Nouvelles recherches stratigraphiques et paléontologiques sur l'Aalénien luxembourgeois. Arch Inst Grand-Ducal Luxembourg Sect Sc Nat Phys Et Math 19:365-397

Maubeuge PL (1994) Sur quelques Hyperlioceras et autres ammonites bajociennes du Musée national d'histoire naturelle de Luxembourg. Bull Soc Nat Lux 95:365-371

Monari S, Gatto R (2013) Pleurotomaria Defrance, 1826 (Gastropoda, Mollusca) from the lower Bajocian (Middle Jurassic) sediments of Luxembourg, with considerations on its systematics, evolution and palaeobiogeographical history. Palaeontology 56(4):751-781

Monari S, Gatto R, Valentini M (2018) Vetigastropoda and Neritimorpha from the Lower Bajocian of Luxembourg and palaeobiogeography of Aalenian-Bajocian (Middle Jurassic) gastropods of western Europe. J Syst Palaeontol 16(6):449-492. https://doi.org/ 10.1080/14772019.2017.1312578

Monari, S. R. Gatto, 2013. The genus Leptomaria E. Eudes-Deslongchamps, 1864 (Gastropoda, Pleurotomariidae) from the Early Bajocian of Luxembourg: systematics and paleobiogeography. 
Historical Biology. https://doi.org/10.1080/08912963.2013. 861461; published online 19 December 2013.

Nel A, Weis R (2017) A new Early Jurassic damselfly from the Grand Duchy of Luxembourg (Odonata: Campterophlebiidae). Alcheringa 41(3):378-382. https://doi.org/10.1080/03115518.2017.1289417

Nel A, Petrulevičius JF, Henrotay M (2004) New Early Jurassic sawflies from Luxembourg: the oldest record of Tentgredinoidea (Hymenoptera: "Symphyta"). Acta Palaeontol Pol 49(2):283-288

Numberger-Thuy LD, Thuy B (2015) An unusual echinoderm assemblage from the earliest Bajocian (middle Jurassic) of Luxembourg, with special emphasis on the ophiuroids (Echinodermata: Ophiuroidea). Ferrantia 71:39-52

Popov EV, Delsate D, Felten R (2019) A new callorhinchid genus (Holocephali, Chimaeroidei) from the early Bajocian of OttangeRumelange, on the Luxembourg-French border. Paleontological Research 23(3):220-230

Sadki D, Weis R, Haas R (2015) Ammonites et bélemnites des « Couches à Sonninia » (Bajocien inférieur) du Grand-duché de Luxembourg. In: Weis R, Thuy B (eds) Le Jurassique au Luxembourg (1) Vertébrés, échinodermes et céphalopodes du Bajocien. Ferrantia 71:53-86

Sadki D, Weis R, Braun P (2020) Graphoceratidés (Ammonitina) de l'Aalénien moyen (Jurassique) de Rumelange-Hutberg (Grandduché de Luxembourg). In: Di Cencio A, Sadki D, Weis R (eds) Paléontologie au Luxembourg (2). Les ammonites de la Minette. Ferrantia 83:104-129

Siehl A, Thein J (1989) Minette-type ironstones. In: Young TP, Taylor WEG (eds) Phanerozoic ironstones. Geological Society Special Publications 46:175-193

Song J, Littke R, Maquil R, Weniger P (2014) Organic facies variability in the Posidonia Black Shale from Luxembourg: implications for thermal maturation and depositional environment. Palaeogeogr Palaeoclimatol Palaeoecol 410:316-336

Storoni A (2010) Les paysages géologiques du Luxembourg. Editions Schortgen, Esch-sur-Alzette

Szwedo J (2011) The Coleorrhyncha (Insecta: Hemiptera) of the European Jurassic, with a description of a new genus from the Toarcian of Luxembourg. Vol Jurass 9(9):3-20

Szwedo J, Weis R, Nel A (2019) A bizarre sternorrhynchan wing from the Lower Jurassic of Luxembourg (Hemiptera: Sternorrhyncha: Pincombeomorpha?). Hist Biol 31(6):806-812. https://doi.org/10. 1080/08912963.2017.1395423

Taverne L, Steurbaut E (2017) Osteology and relationships of Luxembourgichthys ("Pholidophorus") friedeni gen. nov. (Teleostei, "Pholidophoriformes") from the Lower Jurassic of Belgium and the Grand Duchy of Luxembourg. Geologica Belgica 20(1-2):53-67
Teyssen TAL (1984) Sedimentology of the Minette oolithic ironstones of Luxembourg and Lorraine: a Jurassic subtidal sandwave complex. Sedimentology 31:195-211

Thuy B (2003) Les échinides du Bajocien de Rumelange (Grand-duché de Luxembourg). In: Guérin-Franiatte $S$ (ed) Paléontologie au Luxembourg. Ferrantia 36:79-123

Thuy B (2010) An early Bajocian echinoid fauna from Differdange and Pétange (Luxembourg), including a new Rhabdocidaroid species. In: Weis R, Guérin-Franiatte S (eds) Le Jurassique inférieur et moyen au Luxembourg. Nouvelles données paléontologiques et biostratigraphiques. Ferrantia - Travaux scientifiques du Musée national d'histoire naturelle Luxembourg 62:97-114

Thuy B (2010) Note on an early Bahocian diadematoid echinid with attached spines and lantern from Rumelange (NE Paris Basin). In: Weis R, Guérin-Franiatte $\mathrm{S}$ (eds) Le Jurassique inférieur et moyen au Luxembourg. Nouvelles données paléontologiques et biostratigraphiques. Ferrantia 62:115-119

Vincent P, Weis R, Kronz G, Delsate D (2019) Microcleidus melusinae, a new plesiosaurian (Reptilia, Plesiosauria) from the Toarcian of Luxembourg. Geol Mag 156(1):99-116. https://doi.org/10.1017/ S0016756817000814

Waterlot G, Beugnies A, Bintz J, Hary A, Muller A (1973) Guides géologiques régionaux: Ardenne, Luxembourg. Masson, Paris

Weis R (2006) Bélemnites (Cephalopoda, Coleoida) du Bajocien de Rumelange (Luxembourg). Bull Soc Nat Lux 106:151-165

Weis R (2020) Le géopatrimoine au pays des Terres rouges : un héritage naturel à (re)découvrir. Mutations - Mémoires et perspectives du bassin minier 11:41-47

Weis R, Mariotti N (2008) A belemnite fauna from the Aalenian-Bajocian boundary beds of the Grand Duchy of Luxembourg (NE Paris Basin). Boll Soc Paleont Ital 46(2-3):149-174

Weis R, Di Cencio A (2018) Geoheritage in the Red Rock region, southern Luxembourg: towards an integrative view of natural diversity in a cultural landscape? In: Glowniak E, Wasilowska A, Leonowicz P (eds) Geoheritage and conservation: Moderm approaches and applications towards the 2030 Agenda. IX ProGeo Symposium Checiny, Poland 25-28 $8^{\text {th }}$ June 2018, Programme and abstract book:84-85. Faculty of Geology, Warsaw

Weis R, Münzberger P, Colbach R, Lacroix P, Di Cencio A, Korte C, Winther Hougaard I, Thuy B (2019) The 'Dudelange-Neischmelz' core, an exceptionally expanded Pliensbachian-Toarcian succession in the NE Paris Basin (Grand duchy of Luxembourg) providing new insights into Early Jurassic palaeo-environmental change. In: $3^{\text {rd }}$ International Congress on Stratigraphy - STRATI 2019, 2-5 July 2019, Milano, Italy, Abstract Book: p. 427. Società Geologica Italiana, Rome 